\title{
УДК: 62-55:681.515
}

\author{
Микола Олександрович Масесов (кандидат технічних наук, с.н.с) ${ }^{1}$ \\ Вадим Дмитрович Кротов ${ }^{1}$ \\ Павло Вікторович Опенько (кандидат технічних наук, стариий дослідник) ${ }^{2}$
}

\author{
${ }^{1}$ Військовий інститут телекомунікацій та інформатизації імені Героїв Крут, Київ, Украӥна \\ ${ }^{2}$ Національний університет оборони Украӥни імені Івана Черняховського, Київ, Украӥна
}

\section{АКТИВНЕ УПРАВЛІННЯ ЧЕРГОЮ В ТАКТИЧНИХ РАДІОМЕРЕЖАХ 3 ВИКОРИСТАННЯМ НЕЧІТКОЇ ЛОГІКИ}

\begin{abstract}
Діяльність Збройних Сил характеризується специифічними вимогами до інформації, до засобів з6'язку та передачі даних. Аналіз сучасного світового досвіду показує, щзо успішне проведення військових операчій вимагає своєчасного комплексного інформаційного забезпечення бойових дій, що вже неможливе без впровадження сучасних інформаційних технологій.

Для забезпечення зв'язку в умовах впливу деструктивних зовнішніх чинників $i$ відсутності традииійної телекомунікаційної інфраструктури потрібні мережі передачі інформації, щзо мають швидке розгортання, автономність електроживлення кожного вузла, високу живучість, здатність передачі інформачї при випадкових прочесах переміщення, знищення, включення і виключення вузлів. Все ие можливо завдяки використання мобільних Ad-Нос мереж з децентралізованої структурою (Мовіlе Ad-Hoc Networks, MANET) [1, 2]. Основними перевагами побудови МАNET є: реалізація децентралізованого управління компонентами мережі; відсутність фіксованих вузлів; здатність кожного вузла виконувати функиї маршрутизатора. Завдяки вказаним перевагам мережі МАNET мають перспективи застосування для забезпечення зв'язку в тактичній ланці управління, та забезпечать мобільним абонентам можливість безперервного і стійкого обміну інформацією під час знаходження в рухомих об'єктах (КШМ, бронетехнічі, автомобілях) або переміщенні пішим порядком.

Проблема забезпечення якості обслуговування в Аd-Нос мережах, була і залишається актуальною для розробників протоколів, мережевого устаткування і кінцевих користувачів. На всіх рівнях мережі активно використовуються механізми буферизації $i$ управління чергою пакетів, в тому числі $i$ адаптивні, покликані, з одного боку, обслуговувати сплески трафіку з мінімальними втратами пакетів, а з іншого, - забезпечити достатню смугу пропускання і прийнятні тимчасові затримки.

В статті досліджені процеси в тактичній радіомережі з розробленим нечітким регулятором на основі інтерактивної системи MATLAB. Мережа представлена замкненою системою автоматичного керування (системою з активним управлінням чергою) зі змінними параметрами (змінною кількістю комунікаційних каналів чи кількістю сесій TCP (Transmission Control Protocol) N(t) ma часом проходження пакетів туди й назад $R(t))$. Застосування розробленого нечіткого регулятора в тактичній радіомережі є ефективним, дозволяє утримувати поточну довжину черги, близькою до бажаної та ефективну швидкість передачі даних достатню для практичного використання.
\end{abstract}

Ключові слова: Ad-Нос мережі; MATLAB; AQM-система; кількість сесій TCP.

\section{Вступ}

Діяльність збройних сил характеризується специфічними, особливо жорсткими вимогами до інформації і до засобів зв'язку та передавання даних. Аналіз сучасного світового досвіду свідчить, що успішне проведення військових операцій вимагає своєчасного комплексного інформаційного забезпечення бойових дій, що вже неможливе без сучасних інформаційних технологій. Сьогодні наслідки неефективної роботи 3 інформацією - це втрати особового складу, озброєння та військової техніки, які значною мірою зумовлюють перемогу або поразку. Розвідка, аналіз, ухвалення рішення, доведення його до засобів ураження повинні виконуватися в реальному часі 3 мінімальними часовими витратами (це і $€$ скорочення циклу управління).
Саме тому найважливішими напрямками в будівництві Збройних Сил України є створення нових перспективних і вдосконалення існуючих систем управління, пошук нових підходів до організації зв'язку.

Важлива роль відводиться тактичним радіомережам зв'язку (ТРМ), яка надає мобільним абонентам можливість безперервного і стійкого обміну інформацією під час руху (в КШМ, бронетехніці, автомобілях) або переміщенні пішим порядком.

Постановка проблеми. Завдяки високій живучості і розвідзахищеності, швидкого розгортання і можливості доставки інформації в умовах динамічної топології, технологія Ad-Нос Networks має високі перспективи щодо побудови мобільних радіомереж тактичної ланки управління [3]. Але вплив мобільності вузлів 
робить трафік MANET більше нестаціонарним, непередбачуваним, призводить до того, що у кожному каналі мережі спостерігається швидка зміна інтенсивності потоків i, відповідно, пропускній спроможності передачі даних $[1,2] .3$ урахуванням того що, окрім мобільності абонентів (вузлів), функціонування тактичних радіомереж ускладняється впливом деструктивних чинників, можна пояснити той факт, що ТРМ схильна до канальних перевантажень, втрат пакетів, розривів з'єднань. Це тягне до істотного уповільнення передачі даних і зниження продуктивності ТРМ. Для підвищення продуктивності мереж традиційно застосовуються методи, які орієнтовані на забезпечення якості обслуговування (QoS). Під якістю обслуговування розуміють [4] інтегральний корисний ефект від обслуговування, який визначається ступенем задоволення користувача як від отриманої послуги, так і від самої системи обслуговування. Критерій якості обслуговування представляють у вигляді інтегрального показника досконалості обслуговування, що враховує не тільки якість послуги, але і здатність мережі обробляти навантаження.

Функції QoS полягають у забезпеченні гарантованого i диференційованого обслуговування трафіку мережі, за запитами тих чи інших додатків на основі різних механізмів розподілу ресурсів, обмеження інтенсивності трафіку, обробки черг i пріоритезації. QoS $\epsilon$ набором вимог до ресурсів мережі при транспортуванні потоку даних. QoS забезпечує наскрізну гарантію передачі даних і заснований на системі правил, такими як механізм розподілу ресурсів, комутація, маршрутизація, механізми обслуговування черг і механізми відкидання пакетів.

Методи QoS спрямовані на поліпшення характеристик продуктивності і надійності мережі, ці методи дозволяють зменшити затримки, варіації затримок, а також втрати пакетів в моменти перевантаження мережі, створюючи тим самим необхідні умови для задовільного обслуговування трафіку. Тому впровадження удосконалених методів забезпечення QoS в контексті доцільності їх застосування в радіомережах тактичної ланки управління $€$ актуальним науково-технічним завданням.

Аналіз останніх досліджень і публікацій. Аналіз літератури показав, що методи забезпечення якості обслуговування використовують різні механізми, які спрямовані на зменшення негативних наслідків перебування пакетів в чергах із збереженням у той же час позитивної ролі черг. Розробці ефективних методів маршрутизації, у тому числі в MANET, присвячена велика кількість робіт [5-8].

У роботах [9-11] описані i проаналізовані лінеаризовані системи AQM з цими алгоритмами як системи автоматичного управління. Ці системи описані передавальними функціями 3 постійними параметрами, хоча реальні AQM системи $\epsilon$ системами 3 випадковими, стохастичними параметрами.

Серед засобів боротьби 3 мережевими перевантаженнями важливе місце займають методи активного управління чергами. Традиційно обробка перевантаження здійснюється через протокол ТСР, який передає сигнал перевантаження, відкидаючи вхідні пакети, коли черга вузла переповнена i маршрутизатор переповнений (політика відкидання хвоста - TD). На відміну від традиційного управління чергою, яке починає відкидати вхідні пакети, тільки тоді, коли черга вже переповнена, при активному управлінні чергою (AQM) відкидання вхідних пакетів, здійснюється перш, ніж черга буде повна.

Метою протоколу ТСР є установка наскрізного з'єднання, наскрізної доставки пакетів даних, управління потоком i управління перевантаженням. ТСР використовує механізм управління потоком, який заснований на застосуванні вікон. Відправник підтримує змінний розмір вікна, який лімітує число можливих відправлених пакетів. Адресат відправляє підтвердження (ACK) для отриманих пакетів. Принцип вікна пакетної передачі змінної тривалості грунтується на тому, що коли вичерпується розмір вікна, відправник чекає АCK перш, ніж відправити новий пакет. Цей час очікування відомий як період простою для повторної передачі (RTO). Якщо не приходить ACK в продовж цього періоду RTO, то відправник припускає, що пакет втрачений. Втрата пакету відбувається із-за перевантаження в мережі, яка вимагає ТСР запускати механізм управління перевантаженням.

Тактичні радіомережі випробовують динамічні зміни в топології мережі завдяки довільної мобільності вузлів. Зміни топології призводять до частих змін підключення ліній радіозв'язку, і отже маршрути відновлення можуть повторюватися дуже часто. Цей процес відновлення маршруту займає значний час. Час відновлення маршруту $\epsilon$ функцією дальності передачі вузлів, відстанню між джерелом i адресатом, числом проміжних вузлів між відправником і адресатом і вузловою швидкістю. Якщо час відновлення маршруту перевищує період RTO вузла, відправник не отримує ACK i припускає перевантаження в мережі, що супроводжується повторною передачею втрачених пакетів i ініціацією механізму управління перевантаженням. На рис.1 схематично показана переповнена тактична Ad-Hoc радіомережа. Відправник відправляє пакети даних через вузол А, який передає ці пакети на вузол Б $\mathrm{i}$ той відправляе далі одержувачеві. Як тільки канал зв'язку між відправником і вузлом А втрачається, запускається процес відновлення маршруту i створюється прямий канал зв'язку 3 вузлом Б. Якщо час обробки менший, ніж RTO, то відправник отримує ACK i відправляє інші пакети даних, інакше повторно відправляє попередні втрачені пакети. 


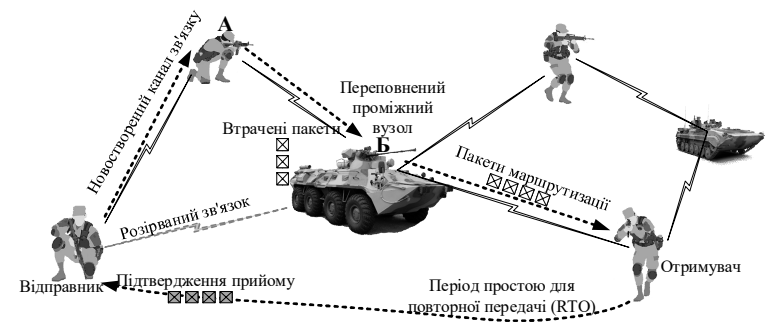

Рис.1. Перевантаження в тактичних радіомережах

Тактичні радіомережі зазнають високе мережеве перевантаження через високий коефіцієнт швидкості бітових помилок (BER) у безпровідному каналі, підвищуються конфлікти через присутність прихованих терміналів, інтерференції, знаходження залежного з'єднання, односпрямованих посилань, пошкоджень маршруту через мобільність вузлів і мінливим властивостям безпровідного каналу. Це обгрунтовує потребу в адаптивних AQM алгоритмах 3 можливостями до високої мінливості i невизначеності притаманних цим типам мереж. Нечітке активне управління чергою може подолати вищезгаданий недолік тактичних мереж.

Коли з'являється перевантаження, вузол використовує одну із стратегій AQM, відкидаючи вхідні пакети даних. Тим часом це дозволяє пакетам управління, проходити в чергу, використовуючи політику відкидання хвоста. Внаслідок цього, пакети даних відкидаються першими, коли вірогідність відкидання пакетів перевищує певний поріг, тоді як пакети управління ще допущені, поки черга не повна.

Повідомлення управління переважно передаються в чергу під час перевантаження 3 наступних причин: 1. Повідомлення управління використовуються, щоб відновити зміни топології мережі. Тому, вони запобігають передачі пакету даних, через пошкоджені маршрути. 2. Пакети даних являються “орієнтовані на з'єднання”, тобто, 3 гарантованою доставкою до місця призначення через ТСР. І навпроти, повідомлення управління являються “без встановлення з'єднання"; тобто, відкинуте повідомлення не передаватиметься повторно. 3. Розмір повідомлення управління $є$ дуже маленьким в порівнянні 3 пакетом даних. Зазвичай у $\mathrm{Ad}-\mathrm{Hoc}$ протоколах маршрутизації, розмір повідомлення управління складає 64 байти, тоді як пакет даних складає 512 байти, тобто, повідомлення управління бере невеликий простір в черзі і швидше обробляється на вузлу.

У роботі [12] використовується нечітка логічна система для обчислення вірогідності відкидання у Ad-Нос мережах на підставі поточного розміру черги і кількості сусідніх вузлів.

Ця схема може бути застосовна у будь-якій мережі, де кількість сусідніх вузлів представлена як кількість комунікаційних каналів зв'язку або, точніше, кількість сесій ТСР.

Поточний розмір черги $q_{c} є$ основною ознакою оцінки вірогідності відкидання вхідних пакетів в політиці AQM. Вірогідність відкидання $p_{d}$ обчислюється як: $p_{d}=2 N^{2} /\left(C T_{p}+q_{c}\right)^{2}$, де $N-$ коефіцієнт навантаження, $C-$ пропускна спроможність (пакети/сек.), і $T_{p}$ - затримка передачі (секунди). Вірогідність відкидання пакету підвищується зі збільшенням навантаження. Зі збільшенням навантаження зростає i кількість пакетів в черзі, які очікують обробки. Таким чином, при збільшенні черги, вірогідність відкидання вхідних пакетів також висока i навпаки. Отже, можна припустити наступні правила:

Правило 1: Якщо $q_{c}$ низький, то $p_{d}-$ низька.

Правило 2: Якщо $q_{c}$ середній, то $p_{d}-$ середня.

Правило 3: Якщо $q_{c}$ великий, то $p_{d}-$ висока.

В тактичних радіомережах, трафік розподіляється по категоріях: пакети даних i повідомлення управління. Повідомлення управління використовуються для безперервного оновлення вузлів при зміні топології (новостворювані або втрачені канали зв'язку). Наприклад, якщо у вузла $є$ два сусідні вузли, то кожну секунду він отримуватиме від них два привітальних повідомлення. Окрім цього, він отримує запит маршруту, повідомлення про ушкодження маршруту або пакети даних. А якщо у вузла десять сусідніх вузлів, то він отримує кожну секунду по десять привітальних повідомлень разом 3 величезною кількістю повідомлень управління і пакетів даних. Отже, трафік менше проходить через вузли 3 меншим оточенням, ніж через вузли 3 великим оточенням. Навантаження $N$ може бути записане як: $N=\sum_{i=0}^{n} \lambda_{i}$, де $\lambda_{i}$ - швидкість потоку від сусіднього вузла $i$, та $n$ - число сусідів. Звідси перевантаження: $p_{d}=1$ якщо $N=\sum_{i=0}^{n} \lambda_{i} \geq C$ і $q_{c}=q_{m}$, де $q_{m}$ - максимальний розмір черги. Отже, при високій концентрації сусідів вузла, черга вузла швидко наповнюється, що веде до збільшення вірогідності перевантаження і навпаки.

Метою статті $\epsilon$ дослідження процесів в тактичній радіомережі 3 розробленим нечітким регулятором, як замкнутої AQM системи 3 випадково змінними параметрами навантаження трафіку (випадковій зміні кількості сесій ТСР $N(t)$ ) і випадковій зміні часу проходження пакетів по колу $R(t)$ на основі інтерактивної системи MATLAB

\section{Виклад основного матеріалу дослідження}

Оскільки кількість сусідніх вузлів (щільність (концентрація) сусідів) представлене кількістю комунікаційних каналів зв'язку або, точніше, кількістю сесій ТСР, то можна використати загальну схему AQM системи, яка скоректована нечітким регулятором (рис. 2), де $N(t)-$ кількість 
сесій, і прийняти, що на нечіткий регулятор в якийсь момент часу 3 кроком квантування $h$ поступають наступні вхідні змінні: помилка $e \equiv$ Error між заданою довжиною черги і реальною довжиною черги $\left(e=\delta q=q_{0}-q\right)$ i швидкість зміни цієї помилки (у практичній схемі нечіткого регулятора замість швидкості використовується перша різниця від змінної “помилка" - $\Delta e)$.

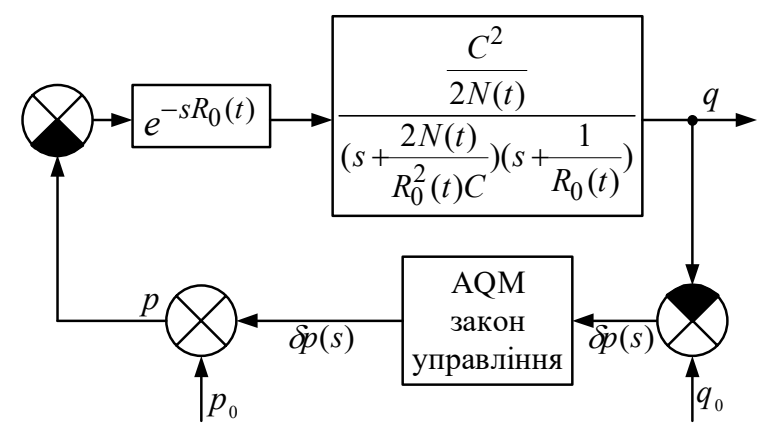

Рис.2. Загальна схема AQM системи, яка скоректована нечітким регулятором

Функції приналежності двох вхідних лінгвістичних змінних (помилки $e \equiv$ Error між заданою довжиною черги і реальною довжиною черги i швидкості зміни цієї помилки $\Delta e$ ) i вихідної лінгвістичної змінної (вірогідність відкидання пакетів) приймемо ідентичними і такими, як приведені на рис.3.

Функції приналежності (ФП) для кожної лінгвістичної величини визначаються по формулах (див. рис. 3):

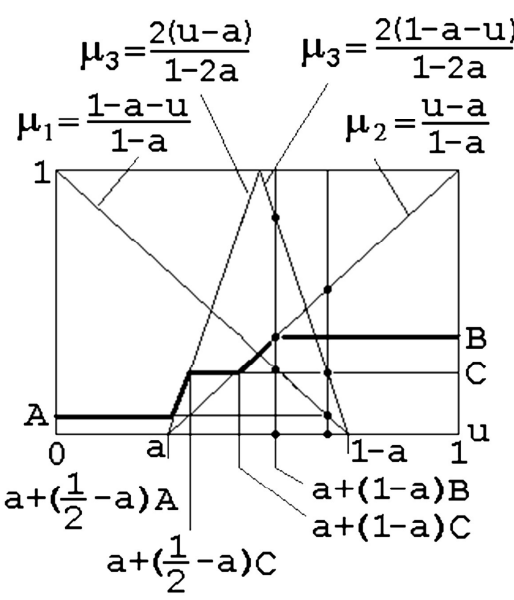

a)

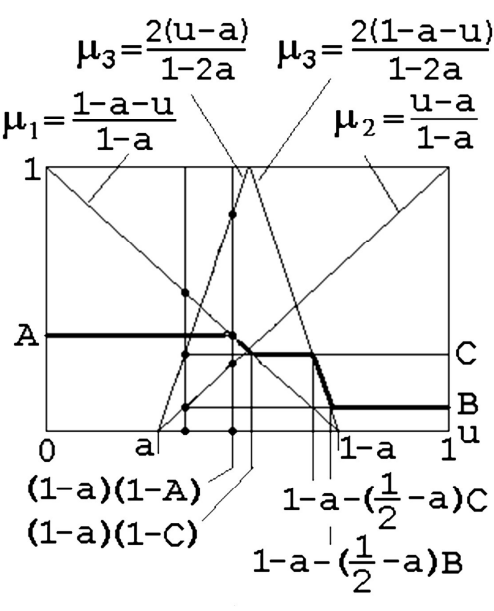

б)

$$
\begin{aligned}
& \mu_{1}(u)=\left\{\begin{array}{c}
\frac{1-a-u}{1-a}, \quad 0 \leq u \leq 1-a ; \\
0,1-a \leq u \leq 1 ;
\end{array} \mu_{2}(u)=\left\{\begin{array}{c}
0, \quad 0 \leq u \leq a ; \\
\frac{u-a}{1-a}, \quad a \leq u \leq 1 ;
\end{array}\right.\right. \\
& \mu_{3}(u)=\left\{\begin{array}{cc}
\frac{2(u-a)}{1-2 a}, \quad a \leq u \leq 1 / 2 ; \\
\frac{2(1-a-u)}{1-2 a}, \quad 1 / 2 \leq u \leq 1-a ; \\
0, \quad 0 \leq u \leq a \text { u } 1-a \leq u \leq 1 .
\end{array}\right.
\end{aligned}
$$

При цьому функція $\mu_{1}(u)$ визначає терм низька, функція $\mu_{2}(u)$ визначає терм висока, а функція $\mu_{3}(u)$ визначає терм середня.

Здійснюється перерахунок вхідних змінних в змінні $u_{1}{ }^{*}, u_{2}{ }^{*}$ на універсальній множині $U=[0,1]$, а потім розрахунок значень ФП для цих змінних (див. рис.3). Точками на універсальній множині відмічені можливі для якогось моменту часу значення змінних $u_{1}{ }^{*}, u_{2}{ }^{*}$.

Які б значення не приймали змінні $u_{1}{ }^{*}, u_{2}{ }^{*}$ на універсальній множині $U=[0,1]$, залежно від співвідношень величин А, В і С “результуюча фігура" може приймати тільки три конфігурації: при $\mathrm{A} \leq C \leq \mathrm{B}$ перша конфігурація зображена на рис. $3 \mathrm{a}$; при $\mathrm{A} \geq C \geq \mathrm{B}$ друга конфігурація зображена на рис. 3б; при $\left\{\begin{array}{l}\mathrm{A} \leq \mathrm{B} \leq \mathrm{C} \\ \mathrm{B} \leq \mathrm{A} \leq \mathrm{C}\end{array}\right.$ третя конфігурація зображена на рис. 3в.

Рис. 3.Функції приналежності для вхідних і вихідних змінних

Абсциса "центру тяжіння результуючої фігури" при $\mathrm{A} \leq C \leq \mathrm{B}$ визначається по формулі [13]

$$
u_{c}=\frac{\left.+\frac{B}{6}+\frac{a^{2}}{2}(A-B)+\left(\frac{a}{2}-a\right)^{2} A^{3}-(1-a)^{2} B^{3}+\left(\frac{3}{4}-a\right) C^{3}\right]}{B+a(A-B)+\left(\frac{1}{4}-\frac{a}{2}\right) A^{2}+\left(\frac{a}{2}-\frac{1}{2}\right) B^{2}+\frac{1}{4} C^{2}}
$$

Абсциса “центру тяжіння результуючої фігури” при $\mathrm{A} \geq C \geq \mathrm{B}$ визначається по формулі [13]

$$
\begin{aligned}
& \frac{A}{2}+\left(a-\frac{a^{2}}{2}\right)(B-A)-\frac{1}{2}(1-a)^{2} A^{2}+\left(\frac{1}{4}-\frac{3 a}{4}+\frac{a^{2}}{2}\right) B^{2} \\
& u_{c}=+\frac{1}{4}(1-a) C^{2}+\frac{1}{6}\left[(1-a)^{2} A^{3}-\left(\frac{1}{2}-a\right)^{2} B^{3}+\left(\frac{3}{4}-a\right) C^{3}\right] \\
& A+a(B-A)+\left(\frac{1}{4}-\frac{a}{2}\right) B^{2}+\left(\frac{a}{2}-\frac{1}{2}\right) A^{2}+\frac{1}{4} C^{2}
\end{aligned}
$$


Абсциса “центру тяжіння результуючої фігури" при $\left\{\begin{array}{l}\mathrm{A} \leq \mathrm{B} \leq \mathrm{C} \\ \mathrm{B} \leq \mathrm{A} \leq \mathrm{C}\end{array}\right.$ визначається по формулі [13]

$$
\begin{aligned}
& \frac{a^{2}}{2} A+\left(a-\frac{a^{2}}{2}\right) B+\left(\frac{1}{2}-a\right) C+\left(\frac{a}{4}-\frac{a^{2}}{2}\right) A^{2} \\
& u_{c}=+\left(\frac{1}{4}-\frac{3 a}{4}+\frac{a^{2}}{2}\right) B^{2}-\left(\frac{1}{4}-\frac{a}{2}\right) C^{2}+\frac{1}{6}\left(\frac{1}{2}-a\right)^{2}\left(A^{3}-B^{3}\right) \\
& C+a(A+B-2 C)+\left(\frac{1}{4}-\frac{a}{2}\right)\left(A^{2}+B^{2}-2 C^{2}\right)
\end{aligned}
$$

Відмітимо, що при фіксованих $A, B$ i $a$ величина $C$ має чітко певне значення. Якщо $A \leq B$, то величина $C$ визначається 3 наступних співвідношень:

$$
\begin{aligned}
& \mu_{1}=\frac{1-a-u^{*}}{1-a}=A ; \quad u^{*}=(1-a)(1-A) ; \\
& \mu_{3}=C=\frac{2\left(1-a-u^{*}\right)}{1-2 a}=\frac{2(1-a) A}{1-2 a} .
\end{aligned}
$$

Якщо $A \geq B$, то величина $C$ визначається 3 наступних співвідношень:

$$
\begin{aligned}
& \mu_{2}=\frac{u^{*}-a}{1-a}=B ; u^{*}=a+(1-a) B ; \\
& \mu_{3}=C=\frac{2\left(u^{*}-a\right)}{1-2 a}=\frac{2(1-a) B}{1-2 a} .
\end{aligned}
$$

Як приклад приведемо наступні результати розрахунків (контрольні точки).

При $\mathrm{A}=0,1, \mathrm{~B}=0,4, \mathrm{C}=0,3, \mathrm{a}=0,25 \Rightarrow u_{c}=0,6158$.

При $\mathrm{A}=0,4, \mathrm{~B}=0,1, \mathrm{C}=0,3, \mathrm{a}=0,25 \Rightarrow u_{c}=0,3842$.

При $\mathrm{A}=0,1, \mathrm{~B}=0,2, \mathrm{C}=0,3, \mathrm{a}=0,25 \Rightarrow u_{c}=0,5491$.

При $\mathrm{A}=0,2, \mathrm{~B}=0,1, \mathrm{C}=0,3, \mathrm{a}=0,25 \Rightarrow u_{c}=0,4509$.

Розглянемо нечіткий регулятор, виконаний за структурною схемою, яку представимо у вигляді послідовного з'єднання трьох блоків (див. рис. 4) [13]: формувача величин $A(t), B(t)$ i $C(t)$ (блок 1), блоку порівняння величин $A, B$ i $C$ і розрахунку $u_{c}$ (блок 2) і блоку нормування вихідний змінної (блок 3 ).

На вхід регулятора поступає помилка системи $\theta=$ Error, а швидкість зміни (перша похідна) помилки $\dot{\theta}$ обчислюється у формувачі за формулою

$$
\dot{\theta}(t) \approx\{\theta(k h)-\theta[(k-1) h]\} / h,
$$

де $h$ - крок квантування (крок надходження інформації на вхід регулятора).

Окрім основних блоків, регулятор має інтегруючу ланку (Integrator), яка включена 3 метою забезпечення в замкнутій системі більш високої точності у встановленому динамічному режимі опрацювання вхідного сигналу (тобто забезпечення меншої динамічної помилки при надходженні заданої довжини черги $\left.q_{o}\right)$, i пропорційну ланку (Gain) 3 малим коефіцієнтом передачі alfo.

Формувач величин $A, B$ і $C$ (блок 1 на рис.4) с трикутними функціями приналежності виконаний за схемою, приведеною на рис. 5. У схемі формувача величин $A(t), \quad B(t)$ i $C(t)$ при налаштуванні нечіткого регулятора перелаштовуються

граничні

значення

симетричних діапазонів

$$
A_{m}=\theta_{\max }=-\theta_{\min }, B_{m}=\dot{\theta}_{\max }=-\dot{\theta}_{\min }
$$

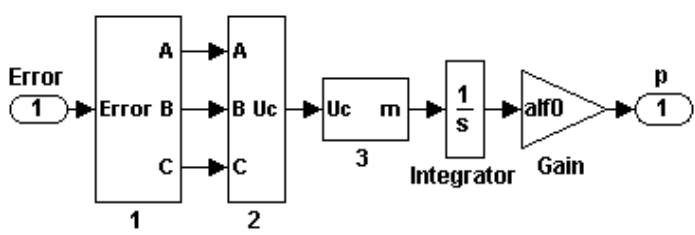

Рис.4. Структурна схема нечіткого регулятора

У блоці нормування вихідної змінної перебудовуються граничні значення діапазону $D_{m}=m_{\max }=-m_{\min } . \quad$ Коефіцієнт $a$ зазвичай задається постійним.

У формувачі величин $A(t)$ i $B(t)$ помилка системи (Error) $\theta^{*}$ квантується АЦП (Zero-Older Hold), обчислюються перша $\dot{\theta}^{*}$ різниця від помилки 3 кроком квантування $h$, і значення вхідних змінних $\theta^{*}, \dot{\theta}^{*}$ перераховуються в змінні $u_{1}^{*}, u_{2}^{*}$ за формулами

$u_{1}^{*}=\left(\theta^{*}+A_{m}\right) /\left(2 A_{m}\right) ; u_{2}^{*}=\left(\dot{\theta}^{*}+B_{m}\right) /\left(2 B_{m}\right)$

Проводиться розрахунок значень вхідних функцій приналежності для змінних $u_{1}{ }^{*}, u_{2}{ }^{*}$ i на основі алгоритму Мамдани визначаються величини $A, B$ і $C$ за формулами:

$$
\begin{aligned}
& A=\min \left[\mu_{1}\left(u_{1}^{*}\right), \mu_{1}\left(u_{2}^{*}\right)\right] \\
& B=\min \left[\mu_{2}\left(u_{1}^{*}\right), \mu_{2}\left(u_{2}^{*}\right)\right. \\
& C=\min \left[\mu_{3}\left(u_{1}^{*}\right), \mu_{3}\left(u_{2}^{*}\right)\right.
\end{aligned}
$$

Значення $A, B$ і $C$ відкладаються відповідним чином на такі ж вихідні функції приналежності і проводиться розрахунок ненормованого виходу регулятора за формулами (2)-(4) у блоці порівняння величин $A(t)$ і $B(t)$ i розрахунку $u_{c}$. Слід зазначити, що блок порівняння реалізує обчислення ненормованого виходу регулятора $u_{c}$ для вихідних функцій приналежності, які ідентичні вхідним.

Далі отримане значення $u_{c}$ у блоці нормування вихідної змінної перераховується у вихідну напругу регулятора за формулою $m^{*}=m_{\min }\left(1-2 u_{c}\right)=2 D_{m} u_{c}-D_{m}$ [13].

Для цього нечіткого регулятора з ідентичними вхідними i вихідними трикутними функціями приналежності (див рис.2) блок порівняння величин $A(t), B(t)$ i $C(t)$ і розрахунку $u_{c}$ (блок 2 на рис. 4) показаний на рис. 6 (a), в, а блок перерахунку величини $u_{c}$ у змінну $m$ (блок 3 на рис. 4) показаний на рис.6 (б). Нечіткий регулятор налаштовується на мінімальну динамічну помилку $\theta(t)=q_{o}-q(t)$. Крок квантування (крок надходження даних в нечіткий регулятор) $h=0,01 c$. 


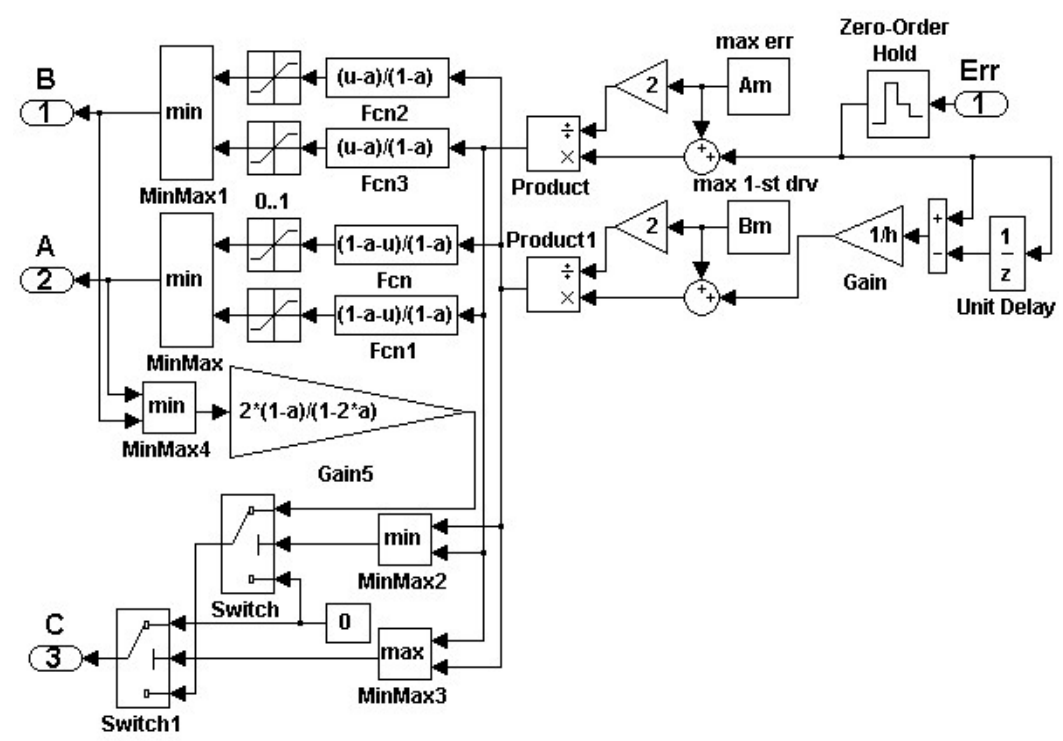

Рис. 5. Формувач величин $A, B$ і $C$

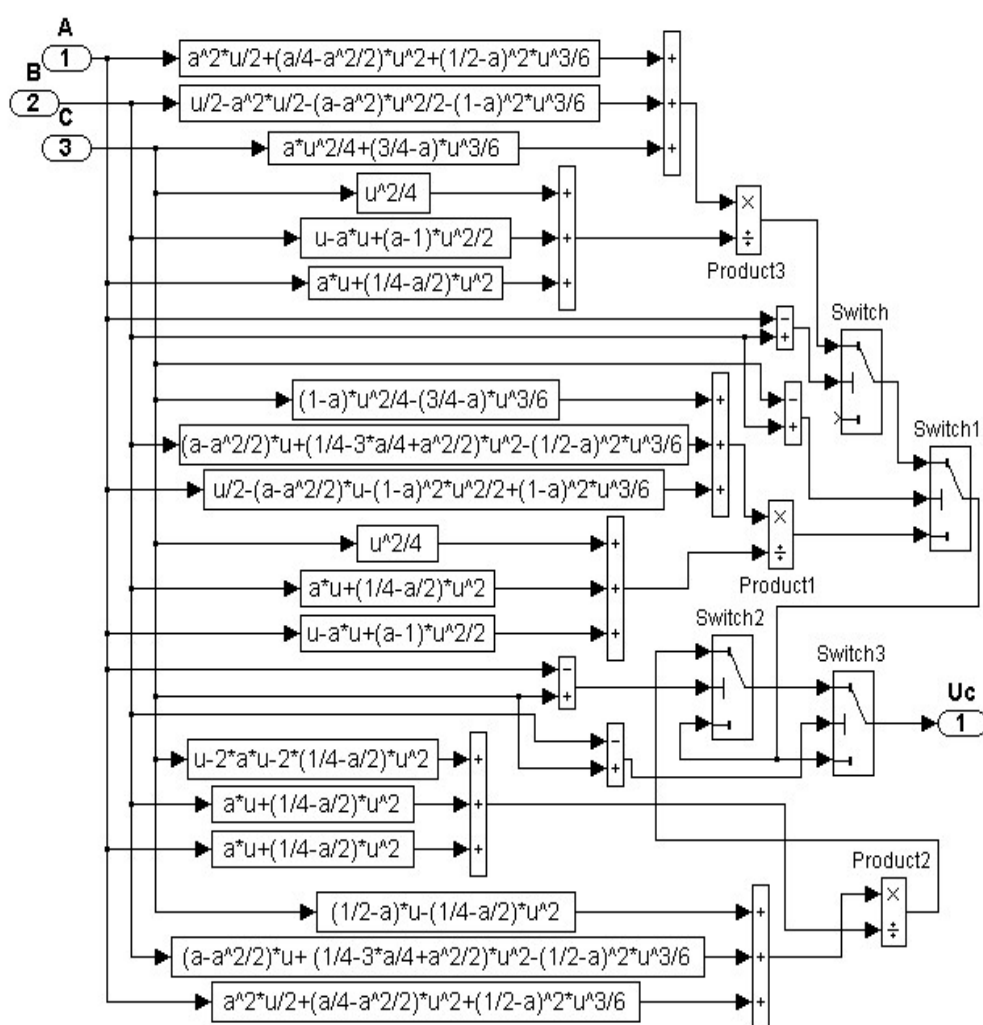

a)

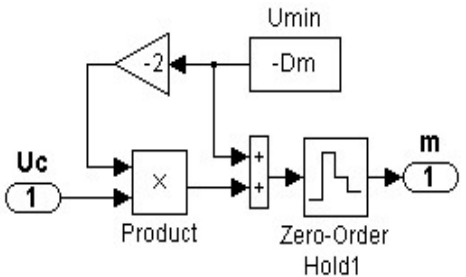

б)

Рис. 6. Блок порівняння величин $A(t), B(t)$ і $C(t)$ i розрахунку $u_{c}($ a) i

блок перерахунку величини $u_{c}$ у змінну $m(б)$

Блок порівняння величин $A(t), B(t)$ i $C(t)$ i розрахунку $u_{c}$ (блок 2 на рис. 4) працює таким чином. На виході подільника Product3 в схемі (див. рис. 6) формується величина $u_{c}$ на підставі формули (2) при $A \leq C \leq B$. На виході подільника Product1 формується величина $u_{c}$ на підставі формули (3) при $A \geq C \geq B$. На виході подільника Product2 формується величина $u_{c}$ на підставі формули (4) при $\left\{\begin{array}{l}\mathrm{A} \leq \mathrm{B} \leq \mathrm{C} \\ \mathrm{B} \leq \mathrm{A} \leq \mathrm{C}\end{array}\right.$.
Перемикачі Switch i Switch1 замикають верхні контакти за умови $A \leq C \leq B$, коли на середніх контактах цих перемикачів сигнали позитивні (у блоках Switch i Switch1 параметр Threshold=0,000001). За умови $A \geq C \geq B$, коли на середніх контактах перемикачів Switch i Switch1 сигнали негативні, перемикачі замикають нижні контакти.

Перемикачі Switch2 і Switch3 замикають верхні контакти за умови $\left\{\begin{array}{l}\mathrm{A} \leq \mathrm{B} \leq \mathrm{C} \\ \mathrm{B} \leq \mathrm{A} \leq \mathrm{C}\end{array}\right.$, коли на середніх 
контактах цих перемикачів сигнали позитивні (у блоках Switch2 i Switch3 параметр Threshold $=0,000001$ ).

За умови $A \leq C \leq B$, коли на середньому контакті перемикача Switch2 сигнал позитивний, а на середньому контакті перемикача Switch3 сигнал негативний, то в перемикачі Switch2 замкнуть верхній контакт, а в перемикачі Switch3 замкнуть нижній контакт.

За умови $A \geq C \geq B$, коли на середньому контакті перемикача Switch3 сигнал позитивний, а на середньому контакті перемикача Switch2 сигнал негативний, то в перемикачі Switch3 замкнуть верхній контакт, а в перемикачі Switch2 замкнуть нижній контакт.

Таким чином, за умови $A \leq C \leq B$ сигнал на вихід схеми поступає 3 виходу подільника Product3, за умови $A \geq C \geq B$ сигнал на вихід схеми поступає 3 виходу дільника Product1 i за умови $\left\{\begin{array}{l}\mathrm{A} \leq \mathrm{B} \leq \mathrm{C} \\ \mathrm{B} \leq \mathrm{A} \leq \mathrm{C}\end{array}\right.$ сигнал на вихід схеми поступає 3 виходу дільника Product2.

В інтерактивній системі MATLAB можна представити модель об'єкту управління з'єднанням ланок, що змінюються випадковим чином, з параметрами $N(t)$ та $R_{o}(t)$ і принципову схему AQM системи, яка скорегована нечітким регулятором, на підставі структурної схеми (див. рис. 2) зобразити у вигляді рис. 7.

Додавання декількох вимірювальних елементів в принципову схему, яка представлена на рис. 7, дає можливість отримати розмір вікна $W$ (у пакетах), а також ефективну швидкість передачі даних $V(t)=W(t) / R$ (пакети/сек), тобто величини, по яким кінцевий споживач оцінює якість каналу зв'язку.

Підсилювальна ланка $C^{2} / 2 / N(t)$ моделюється блоками підсилювачем Gain1 i подільником Product1, на верхній вхід якого поступає сигнал $N(t) \quad$ (рис. 7). Аперіодична ланка $\left[s+2 N(t) / R_{0}^{2}(t) / C\right]$ моделюється інтегратором Integrator, що охоплений негативним зворотним зв'язком, який вмикає помножувач Product, на нижній вхід якого поступає сигнал $N(t)$, подільник Product4, на верхній вхід якого поступає сигнал $R_{o}^{2}(t)$ і підсилювач Gain2 з коефіцієнтом 2/C.

Аперіодична ланка $\left[s+1 / R_{o}(t)\right]$ моделюється інтегратором Integrator1, що охоплений негативним зворотним зв'язком, який вмикає подільник Product2, на верхній вхід якого поступає сигнал $R_{o}(t)$ і підсилювач Gain4 3 коефіцієнтом, що дорівнює одиниці.

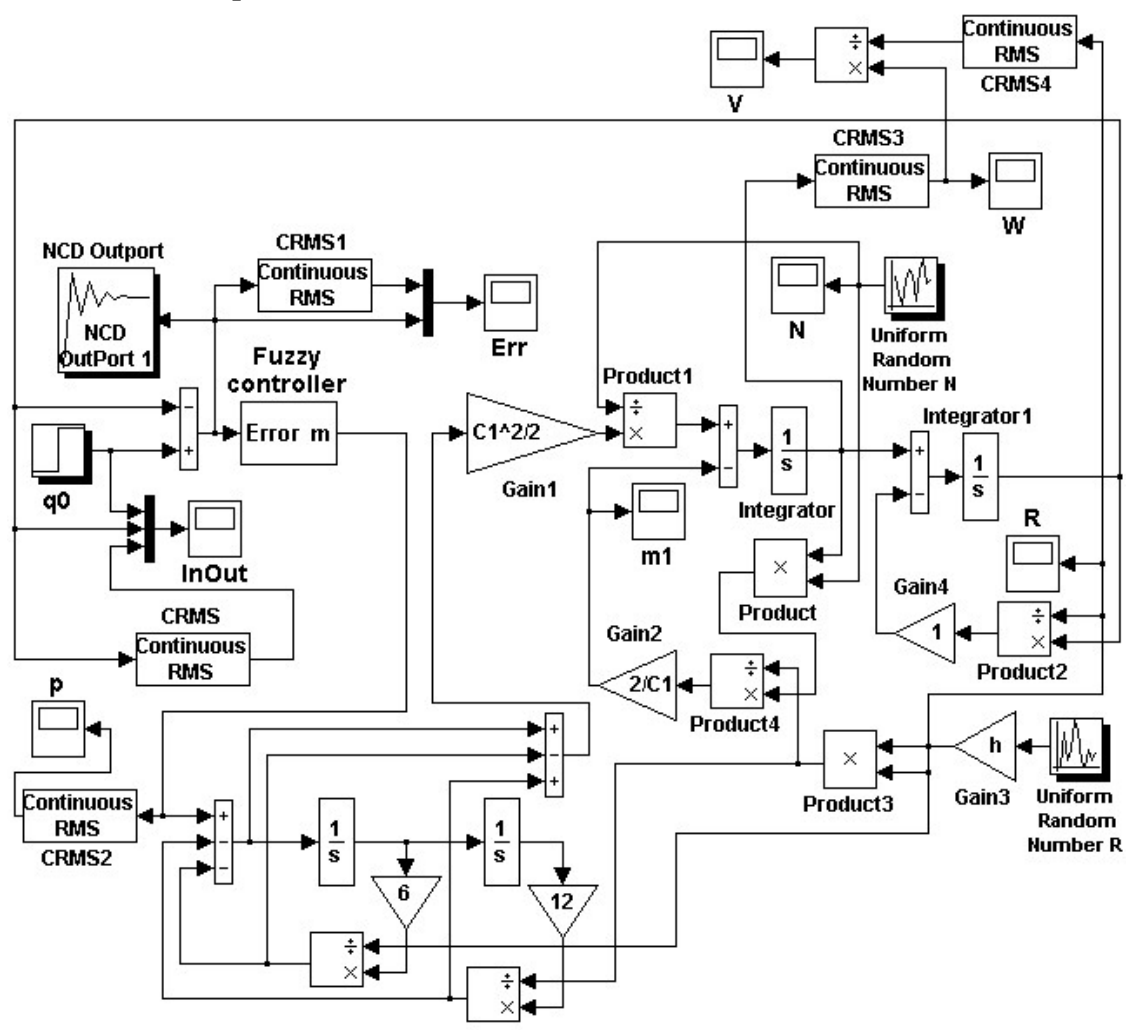

Рис. 7. Модель AQM системи, яка скоректована нечітким регулятором 3 додатковими вимірювальними елементами

Ланка чистого запізнення при апроксимації функцією Паде другого порядку моделюється за допомогою двох інтеграторів, двох підсилювачів 3 коефіцієнтами 6 та 12 і двох подільників на верхні входи яких поступають сигнали $R_{o}(t)$ i $R_{o}^{2}(t)$.

$$
e^{-s R_{o}(t)} \approx \frac{s^{2}-\frac{6}{R_{o}(t)} s+\frac{12}{R_{o}^{2}(t)}}{s^{2}+\frac{6}{R_{o}(t)} s+\frac{12}{R_{o}^{2}(t)}} .
$$

Відзначимо, що при налаштуванні нечіткого 
регулятора в інтерактивній системі MATLAB можна використати блок NCD (Nonlinear Control Design), який реалізує метод динамічної оптимізації для проектування систем управління. Цей інструмент, який розроблений для використання 3 Simulink, автоматично настроює системні параметри (у системі на рис. 7 налаштовуються параметри регулятора), який грунтується на певних обмеженнях на тимчасові характеристики (наприклад, час регулювання реакції на поетапний вплив) або межі динамічної помилки неузгодженості.

Припустимо, що час проходження пакетів туди i назад $R_{o}(t)$ змінюється випадковим чином в межах від 220 мсек до 300 мсек, а навантаження трафіку $N(t)$ змінюється також випадковим чином в межах від 5 до 25. Такі “впливи” на систему (див. рис. 7) можуть генерувати, в інтерактивній системі MATLAB, блоки Uniform Random Number. Відмітимо, що в реальних мережах $\mathrm{i}$ час проходження пакетів туди і назад, і навантаження трафіку може змінюватися випадковим чином в різних межах, але для порівняння роботи регулятора обрані “впливи”, які представлені на рис.8.

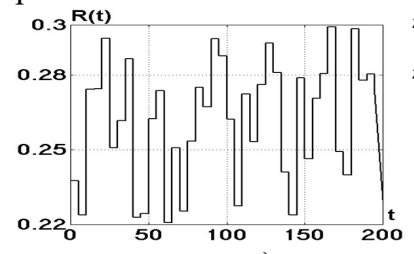

a)

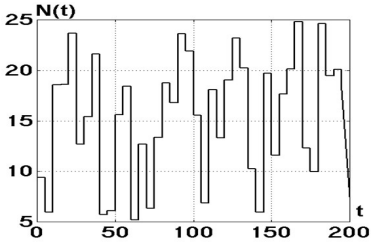

б)
Рис. 8. Час проходження пакетів туди і назад $R_{o}(t)($ a) та навантаження трафіку $N(t)($ б)

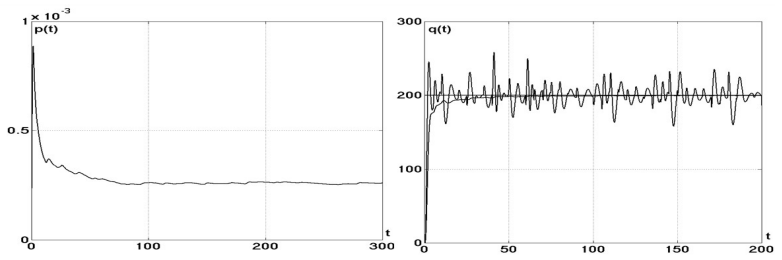

a)

б)

Рис. 9. Вірогідність відкидання/маркування пакетів $p(t)$ і поточна довжина черги $q(t) 3$ нечітким регулятором

Пропускну спроможність мережі оберемо рівною $C=3750$ пакетів/сек, а бажану довжину черги приймемо рівною $q_{0}=200$ пакетів.

Процеси в AQM системі 3 нечітким регулятором, були отримані при наступних параметрах регулятора: $h=0,01 \mathrm{c} ; \quad$ alfo $=10^{-5}$; $A m=1100 ; B m=980 ; D m=2200 ; a=0,25$.

На рис. 9 приведені вихідна змінна FCрегулятора $p(t)$ - вірогідність відкидання/ маркування пакетів 3 виходу блоку CRMS2 (a) i вихід системи $q(t)$ - поточна довжина черги (б) при вказаних параметрах регулятора. Зміни розміру вікна ТСР $W(t)$ представлені на рис. 10: на рисунку (а) функція $W(t)$ знята безпосередньо, а на рисунку (б) - на виході блоку CRMS3. Зміни ефективної швидкості передачі даних $V(t)$ представлені на рис. 11: на рисунку (а) функція $V(t)$ знята безпосередньо, як результат поділення функцій $W(t) / R(t)$, а на рисунку (б) - як результат поділення функцій $W(t) / R(t) \quad 3$ виходів блоків CRMS3 i CRMS4.

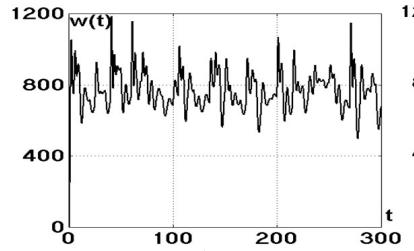

a)

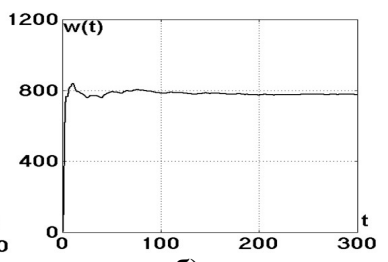

б)
Рис. 10. Зміни розміру вікна ТСР

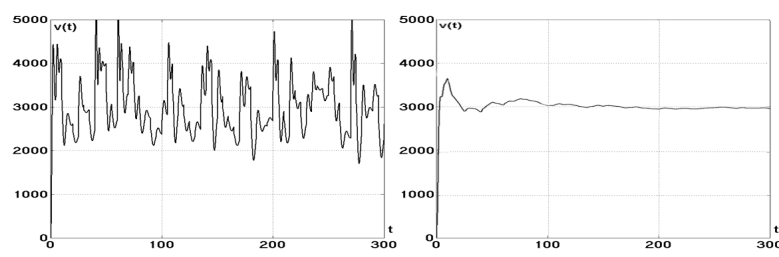

a)

б)

Рис. 11. Ефективна швидкість передачі даних

У інтерактивній системі MATLAB блок CRMS обчислює значення кореня (root mean squared value) 3 суми квадратів квантованої змінної $u(t)$, яка усереднена за інтервал спостереження:

$$
J=\sqrt{\frac{1}{L} \sum_{v=0}^{L-1} u_{v}^{2}},
$$

де $L$ - інтервал спостереження, a $u_{v}, v=0,1,2, \ldots \mathrm{L}-1$ - значення змінної $u(t)$, що квантовані кроком $h$.

3 осцилограм зрозуміло, що середнє значення вірогідності відкидання/маркування пакетів $p(t)$ досить мале - приблизно $2,5 \cdot 10^{-3}$ i встановленому режимі, поточна довжина черги встановлюється 3 високою точністю рівною 200 пакетам (см рис. 9). Встановлене значення розміру вікна ТСР приблизно дорівнює 800 пакетів (см рис. 10), а ефективна швидкість передачі даних (см рис. 11) приблизно дорівнює 3000 пакетам в секунду (що при розмірі пакету у 512 байт рівна $512 \times 8 \times 3000=12,228$ Мбіт/c).

\section{Висновки і перспективи подальших досліджень}

Імітаційне моделювання $є$ базовим засобом розробки телекомунікаційних мереж, що дозволяє оцінити характеристики i обрати параметри налаштування маршрутизації і передачі даних для безпроводових мобільних мереж.

На даний час розроблена значна кількість методів підвищення та забезпечення QoS в телекомунікаційних мережах, але в мобільних радіомережах реалізація далеко не усіх теоретично обгрунтованих управлінських рішень, $\epsilon$ доцільною. Методи, які застосовуються в традиційних безпроводових (або проводових) мережах не ефективно використовувати в мобільних радіомережах, зважаючи на відмінності характеристик цих мереж. У основі ряду методів використовуються цікаві ідеї, застосування яких могло б підвищити ефективність управління інтенсивністю потоків даних в мобільних радіомережах. Проте в ТРМ реалізація цих ідей 
неприйнятна, тому що грунтуючись на досить грубих, наближених моделях, що не сприяє ухваленню адекватних рішень в умовах впливу мобільності абонентів і деструктивних чинників.

При цьому застосування розробленого нечіткого регулятора, який працює 3 протоколом ТСР в тактичних радіомережах, $\epsilon$ ефективним засобом, тому що дозволяє утримувати поточну

\section{Jimepamypa}

1. Mohit K., Rashmi M. An overview of MANET: History, Challenges and Applications. Indian Journal of Computer Science and Engineering (IJCSE). 2012. Vol. 3, No 1. pp. 121-125. 2. Basagni S., Conti M., Giordano S., Stojmenovic I. Mobile ad hoc networking. Wiley-IEEE Press, 2004. 461 р. 3. Разгуляев Л. Перспективные мобильные адаптивные сети передачи информации для СВ США. Зарубежное военное обозрение. 2008. № 1. C. 35-39. URL: http://pentagonus.ru/publ/11-1-0-567

4. Кучерявый Е. Управление трафиком и качество обслуживания в сети Интернет. Наука и техника. 2004. - 336 c. 5. Devaraj S.A., Anita R.H.V., Christa J.J. Comparative analysis of random based mobility models using TCP variant in MANETs. Proceeding of the Sivakasi International Conference Communication and Network Technologies (ICCNT-2014). 2014. P. 324-329. 6. Tseng Y., Li Y., Chang Y. On Route Lifetime in Multihop Mobile Ad-Hoc Networks. IEEE Transactions on Mobile Computing. 2003. vol. 2, No 4, pp. 366-376. 7. Ying Ge, Thomas Kunz and Louise Lamont Quality of Service Routing in Ad-Hoc Networks Using OLSR. Proceeding of the 36th Hawaii International Conference on System Science (HICSS'03). 8. Liao W.H. A Multi-Path довжину черги, близько до бажаної, при високій швидкодії i достатній ефективній швидкості передачі даних.

Подальша робота спрямована на розробку методів оцінювання трафіка та підтримки маршрутів передачі даних в тактичних радіомережах.

QoS Routing Protocol in a Wireless Mobile Ad Hoc Network. IEEE ICN. 2001. 9. Hollot C., Misra V., Towsley D., Gong W. A Control Theoretic Analysis of RED. Proceedings of IEEE INFOCOM 2001. 2001. vol. 3. pp. 1510-1519. 10. Hollot C., Misra V., Towsley D., Gong W. Analysis and design of controllers for AQM routers supporting TCP flows. IEEE/ACM Transactions on Automatic Control. 2002. vol. 47, No 6. pp. 945-959. 11. Hollot C., Misra V., Towsley D., Gong W. On Designing Improved Controllers for Routers Supporting TCP Flows. Proceedings of IEEE INFOCOM'2001. 2001. pp. 1726-1734. 12. Natsheh E., Jantan A.B., Khatun S. Subramaniam S. Fuzzy Active Queue Management for Congestion Control in Wireless Ad-Hoc. The International Arab Journal of Information Technology. 2007, Vol. 4, No. 1, pp. 50-59. 13. Гостев В. І. Проектування нечітких регуляторів для систем автоматичного управління. БХВПетербург, 2011. 416 с. 14. Гостев В.І., Кротов В.Д. Порівняльний аналіз алгоритмів управління чергою при змінних параметрах TCP/IP мереж. Сучасні інформаційні технологї у сфері безпеки та оборони. 2015. № 3. С. 31-37. Режим доступу: http://nbuv.gov.ua/UJRN/sitsbo 201537.

\title{
АКТИВНОЕ УПРАВЛЕНИЕ ОЧЕРЕДЬЮ В ТАКТИЧЕСКИХ РАДИОСЕТЯХ С ИСПОЛЬЗОВАНИЕМ НЕЧЕТКОЙ ЛОГИКИ
}

\author{
Николай Александрович Масесов (кандидат технических наук, с.н.с.) ${ }^{l}$ \\ Вадим Дмитриевич Кротов \\ Павел Викторович Опенько (кандидат технических наук, стариий исследователь) ${ }^{2}$
}

\section{${ }^{1}$ Военный институт телекоммуникаций и информатизации имени Героев Крут, Киев, Украина ${ }^{2}$ Национальный университет обороны Украины имени Ивана Черняховского, Киев}

Деятельность Вооруженных Сил характеризуется специфическими требованиями к информации, к средствам связи и передачи данных. Анализ современного мирового опыта показывает, что успешное проведение военных операций требует своевременного комплексного информационного обеспечения боевых действий, уже невозможно без применения современных информаиионных технологий.

Для обеспечения связи в условиях воздействия деструктивных внешних факторов и отсутствия традиционной телекоммуникационной инфраструктуры нужны сети передачи информации, обладаюшие быстрым развертыванием, автономностью электропитания узлов сети, высокой живучестью, способностью доставлять сообщения при динамически изменяющейся топологии (случайных прочессах перемещения, уничтожения, включение и выключение узлов сети). Достичь таких возможностей можно на основе создания беспроводных самоорганизуюшихся сетей (MANET), имеюших децентрализованную изменяемую структуру. Основными преимуществами построения таких сетей являются: реализация децентрализованного управления компонентами сети; отсутствие фиксированных узлов способность каждого узла выполнять функции маршрутизатора. Благодаря указанным преимуществам сети МАNET имеют перспективы применения для обеспечения связи в тактическом звене управления, и обеспечат мобильным абонентам непрерывный и устойчивый обмен информацией во время передвижения на технике (КШМ, бронетехнике, автомобилях) или пешим порядком.

Проблема обеспечения качества обслуживания в Аd-Нос сетях, была и остается актуальной для разработчиков протоколов, сетевого оборудования и конечных пользователей. На всех уровнях сети активно используются механизмы буферизаџии и управления очередью пакетов, в том числе и адаптивные, которые призваны, с одной стороны, обслуживать всплески трафика с минимальными потерями пакетов, а с другой - обеспечить достаточную полосу пропускания и приемлемые временные задержки.

В статье исследованы процессы в тактической радиосети с разработанным нечетким регулятором на основе интерактивной системь MATLAB. Сеть представлена замкнутой системой 
автоматического управления (системой с активным управлением очередь) с переменными параметрами (переменным числом коммуникационных каналов или числом сессий TCP $N(t)$ и время прохождения пакетов туда и обратно $R(t))$. Применение разработанного нечеткого регулятора в тактической радиосети является эффективным, позволяет удерживать текущую длину очереди, близкой к желаемой и эффективную практическую скорость передачи данных.

Ключевые слова: Ad-Нос сети, MATLAB, AQM-система, число сессий ТCP

\title{
FUZZY LOGIC BASED ACTIVE QUEUE MANAGEMENT IN TACTICAL RADIO NETWORKS
}

\author{
Mykola Masesov (Candidate of Technical Sciences, Senior Research Fellow) ${ }^{l}$ \\ Vadym Krotov ${ }^{1}$ \\ Pavlo Open'ko (Candidate of Technical Sciences, senior researcher) ${ }^{2}$
}

\section{${ }^{1}$ Military Institute of Telecommunications and Informatization named after Heroes Krut, Kiev, Ukraine ${ }^{2}$ National Defence University of Ukraine named after Ivan Cherniakhovskyi, Kyiv, Ukraine}

In context of impact of destructive external factors and the absence of the traditional telecommunications infrastructure necessary information transmission networks with rapid deployment, self-powered nodes, high survivability, ability to deliver messages with dynamically varying topology (random worker processes of network nodes). Such capabilities achieved through the creation of wireless self-organizing networks with decentralized structure (Mobile Ad-Hoc Networks, MANET).

The building such networks main advantages are: implementation of decentralized management of network components; no fixed nodes; each node function a router. The MANET networks have prospects of application to ensure communication in the tactical level. These networks will provide continuous and stable exchange of information both by moving on combat equipment (command and chef machine, armored vehicles, cars) and on foot.

Ensuring the quality of service in Ad-Hoc networks for protocol developers, network equipment and end users still an actual problem. The buffering and query management mechanisms actively used at all levels of network. These mechanisms also include adaptive ones that designed to service traffic bursts minimal lost, and to provide sufficient bandwidth and acceptable time delays.

Processes in mobile tactical radio network with the developed fuzzy controller based on interactive system MATLAB investigated in article. The network presented by the closed loop system of automatic control (system with active queue management) with variable parameters (variable number of communication channels (number of sessions $T C P) N(t)$ and variable round trip time $R(t)$ ). The developed fuzzy controller is effective in tactical radio network. The fuzzy controller use it allows keeping the current queue length close to desired one and effective practical data transfer rate.

Key words: Network Ad-Hoc, MATLAB, AQM-system, number of sessions TCP.

\section{References}

1. Mohit K., Rashmi M. (2012) An overview of MANET: History, Challenges and Applications. Indian Journal of Computer Science and Engineering (IJCSE), Vol. 3, No 1. pp. 121-125. 2. Basagni S., Conti M., Giordano S., Stojmenovic I. (2004) Mobile ad hoc networking. WileyIEEE Press, 461 p. 3. Razgulyaev L. (2008) Prospective adaptive mobile data transmission network for the US Army [Perspektivnyie mobilnyie adaptivnyie seti peredachi informatsii dlya SV SShA], Zarubezhnoe voennoe obozrenie, No. 1, pp. $35-39$. URL: http://pentagonus.ru/publ/11-1-0$\underline{567}$ 4. Kucheryavyiy E. (2004) Traffic management and quality of service on the Internet [Upravlenie trafikom $i$ kachestvo obsluzhivaniya $v$ seti Internet], Nauka i tehnika, 336 p. 5. Devaraj S.A., Anita R.H.V., Christa J.J. (2014) Comparative analysis of random based mobility models using TCP variant in MANETs. Proceeding of the Sivakasi International Conference Communication and Network Technologies (ICCNT). pp. 324-329. 6. Tseng Y., Li Y., Chang Y. (2003) On Route Lifetime in Multihop Mobile Ad-Hoc Networks. IEEE Transactions on Mobile Computing, Vol. 2, No 4, pp. 366-376. 7. Ge Y., Kunz T., Lamont L. (2003) Quality of Service Routing in Ad-Hoc Networks Using OLSR. Proceeding of the 36th Hawaii International Conference on System Science (HICSS'03). 8. Liao W.H. (2001) A Multi-Path QoS Routing Protocol in a Wireless Mobile Ad Hoc Network. IEEE ICN. 9. Hollot C., Misra V., Towsley D., Gong W. (2001) A Control Theoretic Analysis of RED. Proceedings of IEEE INFOCOM, Vol. 3. pp. 1510-1519. 10. Hollot C., Misra V., Towsley D., Gong W. (2002) Analysis and design of controllers for AQM routers supporting TCP flows. IEEE/ACM Transactions on Automatic Control, Vol. 47, No 6. pp. 945-959. 11. Hollot C., Misra V., Towsley D., Gong W. (2001) On Designing Improved Controllers for Routers Supporting TCP Flows. Proceedings of IEEE INFOCOM'2001, pp. 1726-1734. 12. Natsheh E., Jantan A.B., Khatun S., Subramaniam S. (2007) Fuzzy Active Queue Management for Congestion Control in Wireless Ad-Hoc. The International Arab Journal of IT, Vol. 4, No. 1, pp. 50-59. 13. Gostev V.I. (2011) Design of fuzzy controllers for automatic control systems [Proektuvannya nechitkih regulyatoriv dlya sistem avtomatichnogo upravlinnya] St. Peterburg, 416 p. 14. Gostev V.I., Krotov V.D. (2015) Comparative analysis of queue management algorithms for variable parameters of TCP/IP networks [Porivnyalniy analiz algoritmiv upravlinnya chergoyu pri zminnih parametrah TSR/IP merezh] Suchasni Informatsiyni tehnologiyi u sferi bezpeki ta oboroni, Vol. 3. pp. 31-37. URL: http://nbuv.gov.ua/UJRN/sitsbo 201537. 